\title{
FAKTOR PENGARUH MINAT MASUK PERGURUAN TINGGI DI SMK SERANG
}

\author{
M. Nurtanto ${ }^{\text {1) }}$, M. Fawaid $^{2)}$, Y. Fargianti ${ }^{3)}$, S.D. Ramdani ${ }^{4)}$, S. Nurhaji ${ }^{5)}$ \\ ${ }^{1}$ Fakultas Keguruan dan IImu Pendidikan, Universitas Sultan Ageng Tirtayasa \\ email: mnurtanto23@untirta.ac.id \\ ${ }^{2}$ Fakultas Keguruan dan IImu Pendidikan, Universitas Sultan Ageng Tirtayasa \\ email: fawaid80@gmail.com \\ ${ }^{3}$ Fakultas Keguruan dan IImu Pendidikan, Universitas Sultan Ageng Tirtayasa \\ email: yuz.fargianti@gmal.com \\ ${ }^{4}$ Fakultas Keguruan dan Ilmu Pendidikan, Universitas Sultan Ageng Tirtayasa \\ email: s.deni.ramdani@untirta.ac.id \\ ${ }^{5}$ Fakultas Keguruan dan IImu Pendidikan, Universitas Sultan Ageng Tirtayasa \\ email: soffan@untirta.ac.id
}

\begin{abstract}
Abstrak
Tujuan penelitian ini adalah mengetahui seberapa besar minat masuk perguruan tinggi bagi siswa kelas XII program keahlian Teknik Mesin dan Teknik Otomotif di SMK Serang masuk tahun 2016. Metode yang digunakan dalam penelitian ini adalah deskriptif kuantitatif. Sampel penelitian diambil dengan teknik Proportional Random Sampling sejumlah 165 siswa. Teknik pengumpulan data menggunakan angket (kuesioner). Uji validitas instrument dilakukan dengan construct validity melalui experts judgment dengan metode factor analysis. Uji reliabititas menggunakan Alpha. Besarnya minat diuji dengan statistic regresi ganda dengan bantuan SPSS versi 21. Hasil penelitian menunjukkan bahawa minat masuk perguruan tinggi di Serang dengan rerata persentase $71.76 \%$. Minat tersebut dipengaruhi oleh faktor dalam diri sendiri, faktor lingkungan keluarga, dan faktor lingkungan sekolah dengan koefisien regresi masing-masing sebesar 0.199; 0.190; dan 0.090. Faktor diri sendiri dan lingkungan keluarga secara bersama-sama mempengaruhi minat masuk perguruan tinggi sebesar $37,6 \%$.
\end{abstract}

Kata kunci: Minat, Perguruan Tinggi, Diri Sendiri, Sekolah, dan Keluarga

\begin{abstract}
The purpose of this research was to determine interest to enter college for the students class XII of Mechanical Engineering and Automotive Engineering Program at SMK Serang in the year 2016. This research employed quantitative descriptive method. Samples which consist of 165 students were taken by using Proportional Random Sampling technique. The technique of data collection was gained through the use of questionnaire. Validity test of the instrument performed with the construct validity through expert judgment by the method of factor analysis. Reliability test used Alpha. The amount of interest was tested with multiple regression statistics with SPSS version 21. The result indicated that students' interest to enter college in Serang with the average percentage of $71.76 \%$. The interest is influenced by factors within oneself, family environmental factors, and environmental factors of their school with each regression coefficient of 0.199; 0.190; and 0.090. Both of factors within oneself and the family environmental factors are equally affected the interest to enter college by $37.6 \%$.
\end{abstract}

Keywords : students' interest, college, oneself, school, and family. 


\section{PENDAHULUAN}

Pendidikan merupakan langkah strategis membentuk jati diri manusia dalam menemukan kehidupan yang lebih layak yang dibuktikan dengan semakin tinggi pendidikan yang ditempuh mempengaruhi sebuah pekerjaan lebih tinggi pula. Sejalan dengan pernyataan (Ali. M, 2009) bahwa, Pendidikan akan menghasilkan tingkat balikan (return), yaitu tingkat balikan individu (individu return) dan tingkat balikan social (social return). Hal ini menunjukkan, pentingnya pendidikan dalam bidang pekerjaan, sehingga menjadikan kesadaran bersama dalam menentukan ataupun memilih suatu pendidikan yang sesuai guna meningkatkan kualitas diri.

Pengertian pendidikan tercantum dalam UU RI No. 20 tahun 2003 tentang Sistem Pendidikan Nasional (SPN), diartikan sebagai usaha sadar dan terencana untuk mewujudkan suasana belajar dan proses pembelajaran agar peserta didik secara aktif dapat mengembangkan potensi dirinya untuk memiliki kekuatan spiritual keagamaan, pengendalian diri, kepribadian, kecerdasan, akhlak mulia, serta keterampilan yang diperlukan dirinya, masyarakat, bangsa dan Negara. Dengan adanya pendidikan diharapkan dapat meningkatkan indeks pembangunan manusia yang berkualitas serta mampu menguasai pengetahuan dan perkembangan teknologi.

Satuan pendidikan yang menyelenggarakan pendidikan tinggi adalah perguruan tinggi (PT). Peserta didik PT disebut mahasiswa, dimana berasal dari lulusan Sekolah Menengah Atas (SMA), Sekolah Menengah Kejuruan (SMK) dan atau Madarasah Aliyah (MA) berdasarkan tingkat jenjang pendidikan formal di Indonesia. SMK merupakan jenjang pendidikan menengah yang mengutamakan pengembangan keterampilan peserta didik untuk melaksanakan jenis pekerjaan terentu. Sedangkan SMA/MA merupakan jenjang pendidikan menengah yang lebih menekankan pada penguasaan ilmu pengetahuan yang bersifat teoritis sebagai bekal untuk melanjutkan ke jenjang yang lebih tinggi, Ninuk Indrayanti, Siswandari, dan Elvia Ivada (2013). Dengan demikian program pendidikan SMK lebih mengutamakan praktik dan pendidikan SMA/MA meminimalkan praktik atau penguasaan teori.

Pendidikan tinggi di Banten masuk pada kategori yang rendah yaitu sebesar $3,43 \%$ dari pendidikan menengah SMA sebesar $19,40 \%$ dan SMK $2.06 \%$, (Sensus Penduduk BPS tahun 2010). Hal serupa diungkapkan oleh Angka Partisipasi Sekolah (APS) Provinsi Banten berdasarkan data Badan Pusat Statistik (BPS) dari tahun 2011-2015 sebagai berikut:

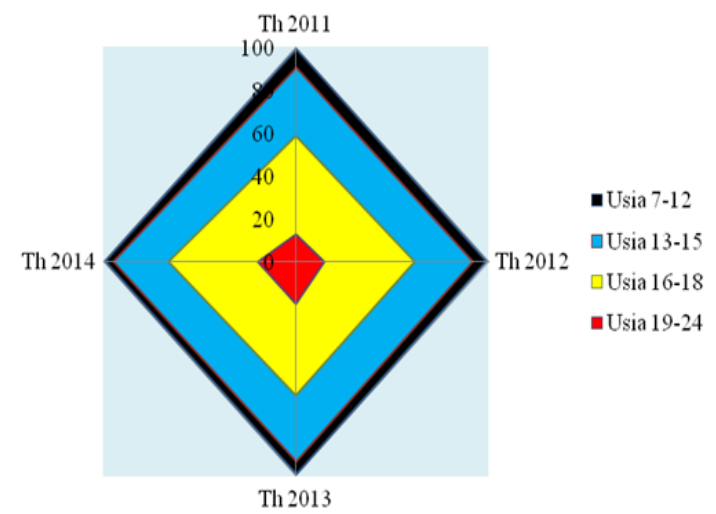

Gambar 1. Angka Partisipasi Sekolah

(APS) Provinsi Banten Tahun 2011-2014 Sumber: (Badan Pusat Statistik, 2016)

Usia 16-18 merupakan masa jenjang pendidikan SMA dan SMK dan usia 19-24 tahun merupan jenjang pendidikan diploma atau sarjana. Pada gambar di atas menunjukkan angka yang terserap untuk melanjutkan perguruan tinggi masih rendah. Sehingga perlu dilakukan penenilitian untuk menentukan minat melanjutkan jenjang yang lebih tinggi dan perlu dilihat pengaruh-pengaruh terhadap minat tersebut.

Minat diartikan sebagai kecendrungan hati yang menetap dalam subjek atau tingkah laku seseorang untuk merasa tertarik pada bidang tertentu dan merasa senang berkecimpung dalam bidang itu, (Djaali, 2011, p. 122; Slameto, 2003, p. 57; W. S. Winkel \& S.j, 1984, p. 
25). Pendapat tersebut diperkuat Williams, K. C. (2013) bahwa "The fact is that human beings in general and students in particular are complex creatures with complex needs and desires". Minat dalam melanjutkan pendidikan yang lebih tinggi dipengaruhi oleh beberapa faktor pendukung, diantaranya diungkapkan Najafian, M. et.al, (2013) dalam hasil penelitiannya menyatakan, "Research results showed six faktors which affect students' interest and direction towards higher education including individual faktors, parents, friends, teachers, media and university's data". Penelitan ini mengkaji minat dan pengaruhnya dalam tiga faktor yaitu dalam diri sendiri, lingkungan keluarga dan lingkungan sekolah sebagai faktor dominan dalam keseharian.

Faktor yang dipengaruhi dari dalam diri sendiri diantaranya motivasi, cita-cita dan keinginan, sejalan dengan pendapat tersebut dikuatkan oleh Suprapto (2007:12) bahwa "salah satu yang mempengaruhi minat adalah motivasi". Hamalik (1992:173) mengungkapkan, motivasi adalah suatu perubahan energi dalam pribadi seseorang yang ditandai dengan timbulnya perasaan (afektif) dan reaksi untuk mencapai tujuan. Cita-cita adalah kehendak yang selalu ada di dalam pikiran seseorang dan akan selalu berusaha mencapainya. Keinginan sama dengan harapan. Pada saat ada keinginan dari siswa untuk melanjutkan ke perguruan tinggi maka siswa tersebut akan berusaha mencapai tujuan tersebut.

Faktor yang dipengaruhi lingkungan keluarga disebabkan beberapa hal diantaranya pendidikan keluarga dan ekonomi keluarga. Pendidikan keluarga yang tinggi akan mendukung kemauan anak bahkan akan mengarahkan potensi anak. Sedangkan kondisi ekonomi yang kecukupan memudahkan orang tua dalam pembiayaan atau memilih perguruan tinggi yang diinginkan. Sejalan dengan Okioga, C.K. (2013), "Lower incomes families can have children who do not succeed to the levels of the middle income children have a greater sense of entitlement, more argumentative, or better prepared for adult life". Rendahnya pendapatan orang tua mempengaruhi keberhasilan anak. Diperkuat oleh Davis-Kean P.E. (2005), "Parents' years of schooling also was found to be an important socioeconomic faktor to take into consideration in both policy and research when looking at school-age children".

Faktor yang mempengaruhi minat berdasarkan lingkungan sekolah terdiri dari tiga peran yaitu alumni, teman dan guru yang mendukung dalam melanjutkan masuk perguruan tinggi. Alumni pada lingkungan sekolah berdampak pada ketertarikan pada siswa untuk memperoleh pandangan memilih perguruan tinggi. Teman dan guru merupakan pendukung dalam mencari informasi sebanyak-bannyaknya.

\section{METODE}

Penelitan ini menggunakan desain penelitian deskriptif kuantitatif yaitu dengan menggunakan gabungan desain penelitian deskriptif dan kuantitatif bertujuan untuk memperoleh gambaran sebenarnya sehubungan dengan minat siswa SMK di Serang untuk melanjutkan pendidikan yang lebih tinggi.

Populasi dalam penelitian ini adalah seluruh siswa kelas XII SMK program keahlian TKR dan TMP di Serang tahun 2016 yang berjumlah 279 siswa, yang terdiri dari 4 sekolah. Teknik penentuan sampel dalam penelitian ini dengan teknik Proportional Random Sampling yang menggunakan Nomogram Harry King. Besarnya sampel yang dikehendaki mempunyai taraf kepercayaan 95\%. Dari populasi 279 siswa, jumlah sampel yang diperlukan $0.59 \times 279=165$ siswa.

Berdasarkan tujuan dari penelitian ini, dalam pengumpulan data sesuai dengan karakteristik penelitian, maka menggunakan angket (kuesioner), untuk mendapatkan data minat masuk perguruan tinggi dan faktor-faktor yang mempengaruhi minat. Penyusunan isntrumen angket menggunakan skala likert dengan dua jenis pernyataan yaitu pernyataan positif dan pernyataan negative dengan skor alternative jawaban sebagai berikut: 
Tabel 1. Skor Pernyataan

\begin{tabular}{lccl}
\hline \multicolumn{2}{c}{ Pernyataan Positif } & \multicolumn{2}{c}{ Pernyataan Negatif } \\
\hline $\begin{array}{l}\text { Alternatif } \\
\text { Jawaban }\end{array}$ & Skor & Skor & $\begin{array}{l}\text { Alternatif } \\
\text { Jawaban }\end{array}$ \\
\hline Sangat Setuju & 4 & 1 & Sangat Setuju \\
Setuju & 3 & 2 & Setuju \\
Tidak Setuju & 2 & 3 & Tidak Setuju \\
Sangat Tidak & 1 & 4 & $\begin{array}{l}\text { Sangat Tidak } \\
\text { Setuju }\end{array}$ \\
Setuju & & & \\
\hline
\end{tabular}

Data yang sudah terkumpul dan dikelompokan selanjutnya dilakukan analysis deskriptif berdasarkan tingkat kategorinya. Analisis deskriptif tersebut, menggunakan persamaan sebagai berikut.

$$
P=\frac{n}{N} X 100 \%
$$

Keterangan:

$P$ : Deskripsi prosentase

$\mathrm{n}$ : Jumlah skor yang diperoleh

$\mathrm{N}$ : Jurnal skor idel (skor maksimal)

Sumber: Ali Mohamad (1985:184)

Langkah selanjutnya dideskripsikan sesuai kategori perolehan sesuai jumlah indikator dari setiap variabel. Penentuan kategori menggunakan formula berikut.

Tabel 2. Kategori Tingkat Perolehan

\begin{tabular}{ll}
\hline \multicolumn{1}{c}{ Formula } & \multicolumn{1}{c}{ Kategori } \\
\hline $\mathrm{X}<(\mathrm{Mi}-1,5 . \mathrm{SDi})$ & Sangat Tinggi \\
\hline$(\mathrm{Mi}-1,5 . \mathrm{SDi})=\mathrm{X}<\mathrm{Mi}$ & Tinggi \\
\hline $\mathrm{Mi}=\mathrm{X}<(\mathrm{Mi}+1,5 . \mathrm{SDi})$ & Rendah \\
\hline (Mi+1,5.SDi $)=\mathrm{X}$ & Sangat Rendah \\
Sumber: Diadaptasi dari Djemari \\
Mardapi (2008).
\end{tabular}

Analisis faktor bertujuan untuk mengelompokkan data menjadi beberapa kelompok sesuai dengan hubungan korelasi antar variabel. Analisis faktor juga digunakan untuk menyederhanakan hubungan yang sangat kompleks pada variabel yang diamati dengan menyatukan dimensi yang dimiliki korelasi pada struktur data baru dengan satuan faktor yang lebih kecil.
Hasil analisis variabel minat dan pengaruh diri sendiri, lingkungan keluarga dan lingkungan sekolah dilihat melalui KMO (Kaiser-Meyer-Olkin of Samling Aduque) dengan membandingkan hasil $>0.5$ dan Bartlett's Test of Sphericity dibandingkan hasil $<0.05$. variabel minat diperoleh $0.719>0.5$ dengan sig. $0.00<0.05$ (Valid); Variabel Pengaruh diri sendiri diperoleh $0.870>0.5$ dengan sig. $0.00<0.05 \quad$ (Valid); variabel pengaruh lingkungan keluarga diperoleh $0.619>0.5$ dengan sig. $0.00<0.05$ (Valid); dan pengaruh lingkungan sekolah diperoleh $0.739>0.5$ dengan sig. $0.00<0.05$ (Valid). Nilai perolehan menunjukkan bahwa faktor pembentuk variabel sudah baik dan dapat digunakan untuk penelitian pada sampel yang lebih besar.

Uji validitas data menggunakan korelasi Product Moment antar variabel dengan bantuan Program SPSS versi 21. Hasil uji coba instrument sebanyak 35 pernyataan yang telah diujikan pada 35 responden, setelah dilakukan pengujian validitas dan reliabilitas dua pernyataan dinyatakan guru yaitu butir pernyataan 11 pada variabel diri sendiri dan 28 pada variabel lingkungan sekolah. Uji reliabilitas menggunakan formula Alpha.

Besarnya minat dianalisa dengan metode dekriptif dan faktor-faktor yang mempengaruhi minat masuk perguruan tinggi diuji dengan statistic yaitu dengan regresi ganda dengan persamaan $\hat{Y}=a+$ $b_{1} X_{1}+b_{2} X_{2}+b_{3} X_{3}$.

\section{HASIL DAN PEMBAHASAN \\ HASIL MINAT DAN FAKTOR PENGARUH}

Data hasil penelitian terhadap pernyataan-pernyataan yang tertuang pada angket berupa data kuantitatif. Dari data yang diperoleh selanjutnya dianalisis menggunakan statistic dengan rumus deskriptif persentase.

Hasil dari presentase kemudian ditafsirkan ke dalam kalimat yang bersifat deskriptif kuantitatif. Minat masuk perguruan tinggi bagi siswa SMK kelas XII program keahlian Teknik Mesin dan Teknik Otomotif di Serang, secara kulitatif berdasarkan data yang diperoleh dan 
dianalisis dengan deskripsi prosentase disajikan pada diagram vent berikut.

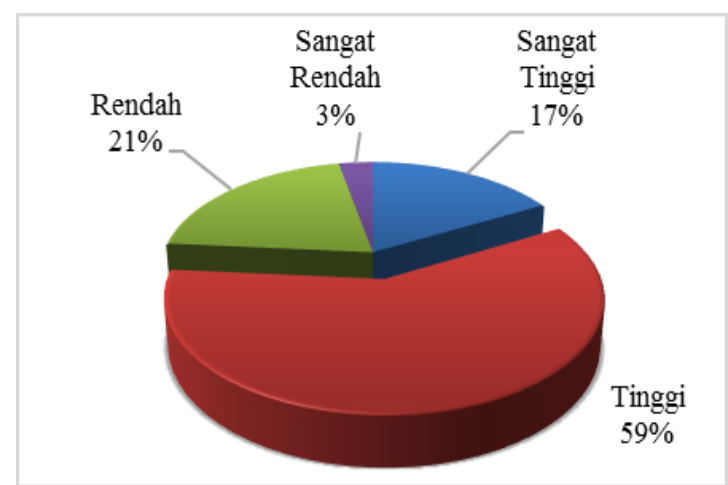

Gambar 2. Diagram Vent Minat Masuk Perguruan Tinggi SMK Kelas XII di Serang

Gambar 2. menunjukkan sebagian besar siswa SMK kelas XII di Serang yaitu $17 \%$ pada kategori "sangat tinggi", $59 \%$ kategori "tinggi", 21\% kategori rendah sedangkan kategori selebihnya sangat rendah sebesar 3\%. Minat masuk perguruan tinggi dipengaruhi beberapa faktor diantaranya faktor dalam diri sendiri, faktor lingkungan keluarga dan faktor lingkungan sekolah.

Faktor pengaruh dalam diri sendiri, berdasarkan hasil analisis deskriptif persentase dari masing-masing pernyataan sebanyak 3 (tiga) indikator yaitu motivasi, cita-cita, dan keinginan. Faktor pengaruh lingkungan keluarga berdasarkan hasil analisis deskriptif prosentase dari pernyataan sebanyak 2 (dua) indikator yaitu pendidikan dan ekonomi. Sedangkan faktor pengaruh dari lingkungan sekolah terdiri dari 3 (tiga) indikator yaitu alumni, teman dan guru. Dari masing-masing indikator tersebut ditampilkan pada table berikut.

Tabel 3. Faktor Pengaruh Minat Masuk Perguruan Tinggi berdasarkan Indikator Diri Sendiri, Lingkungan Keluarga, dan Lingkungan Sekolah

\begin{tabular}{|c|c|c|c|c|c|c|c|c|}
\hline \multirow{2}{*}{ Indikator } & \multicolumn{2}{|c|}{ Sangat Tinggi } & \multicolumn{2}{|c|}{ Tinggi } & \multicolumn{2}{|c|}{ Rendah } & \multicolumn{2}{|c|}{ Sangat Rendah } \\
\hline & Frekuensi & (\%) & Frekuensi & (\%) & Frekuensi & (\%) & Frekuensi & (\%) \\
\hline Motivasi & 104 & $63.0 \%$ & 33 & $20.0 \%$ & 12 & $7.3 \%$ & 16 & $9.7 \%$ \\
\hline Cita-cita & 70 & $42.4 \%$ & 63 & $38.2 \%$ & 17 & $10.3 \%$ & 15 & $9.1 \%$ \\
\hline Keinginan & 116 & $70.3 \%$ & 18 & $10.9 \%$ & 12 & $7.3 \%$ & 19 & $11.5 \%$ \\
\hline Pendidikan & 70 & $42.4 \%$ & 60 & $36.4 \%$ & 14 & $8.5 \%$ & 21 & $12.7 \%$ \\
\hline Ekonomi & 41 & $24.8 \%$ & 78 & $47.3 \%$ & 39 & $23.6 \%$ & 7 & $4.2 \%$ \\
\hline Alumni & 76 & $46.1 \%$ & 56 & $33.9 \%$ & 19 & $11.5 \%$ & 14 & $8.5 \%$ \\
\hline Teman & 22 & $13.3 \%$ & 83 & $50.3 \%$ & 51 & $30.9 \%$ & 9 & $5.5 \%$ \\
\hline Guru & 9 & $5.5 \%$ & 103 & $62.4 \%$ & 48 & $29.1 \%$ & 5 & $3.0 \%$ \\
\hline
\end{tabular}

Sumber: Data kuesioner

Table 3. di atas menunjukkan bahwa indikator dengan frekuensi tertinggi adalah keinginan sebanyak 116 responden $(70.3 \%)$ dan Motivasi sebanyak 104 responden (63.0\%). Pada kategori tinggi indikator terbanyak adalah guru sebanyak 103 responden $(62.4 \%)$ dan teman sebanyak 83 responden (50.3\%). Sedangkan kategori rendah paling sedikit adalah motivasi dan keinginan sebanyak 12 responden (7.3\%) sedangkan kategori sangat rendah paling sedikit pada indikator guru dan ekonomi masing- masing sebanyak 5 responden (3.0\%) dan 7 responden (4.2\%). Jumlah frekuensi tinggi dan sangat tinggi tiga terbanyak diantaranya motivasi, keinginan dan citacita masing-masing berjumlah 137 $(83,0 \%), 134$ (81.2\%) dan 133 (80.6\%) dari 165

Pengaruh minat berdasarkan diri sendiri yang terdiri dari motivasi, cita-cita dan keinginan, frekuensi tertinggi adalah keinginan sebanyak 116 orang. Pengaruh minat berdasarkan faktor lingkungan keluarga meliputi pendidikan dan ekonomi, 
dengan frekuansi tertinggi adalah pendidikan sebanyak 70 orang. Sedangkan faktor pengaruh lingkungan sekolah terdiri dari alumni, teman dan guru, frekuansi tertinggi adalah alumni sebanyak 76 orang.
Berdasarkan table 3. di atas perlunya dikelompokkan dalam variabel pengaruh minat sebagai berikut:

Tabel 4. Faktor Pengaruh Minat Masuk Perguruan Tinggi berdasarkan Variabel Diri Sendiri, Lingkungan Keluarga, dan Lingkungan Sekolah

\begin{tabular}{|c|c|c|c|c|c|c|c|c|c|c|}
\hline \multirow{2}{*}{ Indikator } & \multirow{2}{*}{ Mean } & \multirow{2}{*}{ Kategori } & \multicolumn{2}{|c|}{ ST } & \multicolumn{2}{|c|}{$T$} & \multicolumn{2}{|c|}{$\mathbf{R}$} & \multicolumn{2}{|c|}{ SR } \\
\hline & & & Frek & (\%) & Frek & (\%) & Frek & (\%) & Frek & (\%) \\
\hline Diri Sendiri & 77.63 & $T$ & 104 & $63.0 \%$ & 33 & $20.0 \%$ & 12 & $7.3 \%$ & 16 & $9.7 \%$ \\
\hline $\begin{array}{l}\text { Lingk. } \\
\text { Keluarga }\end{array}$ & 70.51 & $\mathrm{~T}$ & 41 & $24.8 \%$ & 78 & $47.3 \%$ & 39 & $23.6 \%$ & 7 & $4.2 \%$ \\
\hline $\begin{array}{l}\text { Lingk. } \\
\text { Sekolah }\end{array}$ & 65.32 & $\mathrm{~T}$ & 9 & $5.5 \%$ & 103 & $62.4 \%$ & 48 & $29.1 \%$ & 5 & $3.0 \%$ \\
\hline
\end{tabular}

Sumber: Data Kuesioner

Setelah dikelompokkan dalam variabel pengaruh minat diperoleh mean untuk diri sendiri sebesar 77.63 pada kategori deskriptif "tinggi". Sedangkan faktor pengaruh keluarga dengan mean sebesar 70.51 pada kategori "tinggi" sedangkan untuk faktor pengaruh lingkungan sekolah, mean dperoleh sebesar 65.32 pada kategori "tinggi".

\section{HASIL ANALISIS REGRESI GANDA}

Berdasarkan hasil uji linieritas hubungan variabel dependen dan variabel independen yang menyatakan bahwa asumsi linier dalam penelitian ini terpenuhi, maka penelitian menggunakan analisis regresi ganda. Hasil dari koefisien-koefisien regresi menunjukan pola pengaruh antar variabel bebas dan variabel terikat. Hasil analisis regresi ganda yang dilakukan dengan SPSS versi 21. Sebagai berikut:

Coefficients $^{\mathrm{a}}$

Tabel 5. Hasil Analisis Regresi Ganda

\begin{tabular}{|c|c|c|c|c|c|c|c|c|}
\hline \multirow{2}{*}{\multicolumn{2}{|c|}{ Model }} & \multicolumn{2}{|c|}{$\begin{array}{c}\text { Unstandardized } \\
\text { Coefficients }\end{array}$} & \multirow{2}{*}{$\begin{array}{c}\begin{array}{c}\text { Standardized } \\
\text { Coefficients }\end{array} \\
\text { Beta }\end{array}$} & \multirow[t]{2}{*}{$\mathrm{T}$} & \multirow[t]{2}{*}{ Sig. } & \multicolumn{2}{|c|}{$\begin{array}{l}95.0 \% \text { Confidence Interval } \\
\text { for B } \\
\end{array}$} \\
\hline & & $B$ & $\begin{array}{l}\text { Std. } \\
\text { Error }\end{array}$ & & & & $\begin{array}{l}\text { Lower } \\
\text { Bound }\end{array}$ & $\begin{array}{l}\text { Upper } \\
\text { Bound }\end{array}$ \\
\hline & (Constant) & 1.261 & 1.017 & & 1.239 & .217 & -.748 & 3.270 \\
\hline & $\begin{array}{l}\text { Diri Sendiri } \\
\quad(X 1)\end{array}$ & .199 & .024 & .548 & 8.209 & .000 & .151 & .247 \\
\hline 1 & $\begin{array}{l}\text { Lingkungan } \\
\text { Keluarga (X2) }\end{array}$ & .180 & .050 & .222 & 3.628 & .000 & .082 & .278 \\
\hline & $\begin{array}{l}\text { Lingkungan } \\
\text { Sekolah (X3) }\end{array}$ & .090 & .038 & .138 & 2.332 & .021 & .014 & .165 \\
\hline
\end{tabular}

Sumber: Analisis SPSS Versi 21.

Berdasarkan table 5. di atas dapat dibuat persamaan regresi ganda sebagai berikut: $Y=1.261+0.199 \mathrm{X} 1+0.180 \mathrm{X} 2$ +0.090 X3. Dari persamaan tersebut dapat dimaknai sebagai berikut: (1) konstanta $=1.261$, variabel faktor diri sendiri, lingkungan keluarga dan lingkungan sekolah bernilai "0". Maka minat siswa dalam melanjutkan perguruan tinggi sebesar 1.261; (2) koefisien $\mathrm{X} 1=$ 
0.199, menyatakan bahwa setiap peningkatan 1 point faktor diri sendiri, maka akan meningkatkan siswa melanjutkan ke perguruan tinggi sebesar 0.199; (3) koefisien X2 = 0.180, menyatakan bahwa setiap peningkatan 1 point faktor lingkungan keluarga, maka akan meningkatkan siswa melanjutkan ke perguruan tinggi sebesar 0.180 ; dan (4) koefisien X3 $=0.090$, menyatakan bahwa setiap peningkatan 1 point faktor lingkungan sekolah, maka akan meningkatkan siswa melanjutkan ke perguruan tinggi sebesar 0.090 .

Hasil analisis regresi ganda menunjukkan nilai konstanta (1.261) lebih besar dibandingkan nilai-nilai koefisien lainnya. Hal ini menunjukkan bahwa, faktor-faktor pengaruh diri sendiri, lingkungan keluarga, dan lingkungan sekolah memberikan sumbangan yang sangat kecil. Berdasarkan faktor di atas maka dapat disimpulkan bahwa masih ada faktor lain yang mempengaruhi minat siswa dalam melanjutkan ke perguruan tinggi.

Pengujian hipotesis menggunakan uji $F$ (secara simultan) dan uji t (secara parsial). Hasil pengujian uji $F$ diperoleh

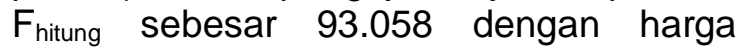
sigifikansi 0.000 sedangkan $F_{\text {tabell }}$ $(4,161 ; 0,05)$ yang diperoleh dari distribusi $\mathrm{F}$ dengan $\mathrm{df}=4$ dan alpa $5 \%$ diperoleh $F_{\text {tabel }}$ sebesar 2.66. Dengan demikian Ho di tolak dimana $F_{\text {hitung }}>F_{\text {tabel. }}$. Hipotesa yang menyatakan tidak ada pengaruh faktor diri sendiri, faktor lingkungan keluarga, dan faktor lingkungan sekolah tidak dapat diterima. Begitu juga sebaliknya, $\mathrm{Ha}$ yang menyatakan ada pengaruh dalam diri sendiri, lingkungan keluarga dan lingkungan sekolah terhadap minat siswa dapat diterima. Hal ini membuktikan bahwa minat masuk perguruan tinggi dapat mempengaruhi faktor diri sendiri, lingkungan keluarga, dan lingkungan sekolah.

Drajat hubungan faktor dalam diri sendiri dan lingkungan keluarga terhadap minat melanjutkan perguruan tinggi diperoleh harga koefisien $(R)$ sebesar 0.616 . keberartian dari koefisien korelasi secara simultan, dan dilakukan uji F, maka dapat disimpulkan hubungan faktor diri sendiri dan lingukungan keluarga signifikan. Besarnya pengaruh faktor diri sendiri dan lingkungan keluarga dapat diketahu dengan harga koefisien determinasi secara simultan $\left(R_{2}\right)$. Berdasarkan analisis $R_{2}$ diperoleh 0.376. dapat disimpulkan faktor diri sendiri dan lingkungan keluarga secara bersamasama mempengaruhi minat masuk perguruan tinggi sebesar $37,6 \%$

\section{PEMBAHASAN}

Minat muncul disebabkan adanya keinginan yang cenderung menetap pada diri seseorang untuk mengarahkan pada suatu pilihan tertentu sebagai kebutuhannya, selanjutnya langkah tindakan untuk mewujudkan pilihannya dengan mengemas informasi sebanyakbanyaknya. Hasil penelitian angket menunjukkan bahwa minat masuk perguruan tinggi memiliki mean $71.76 \%$ pada kategori "tinggi". Faktor pengaruh dalam diri sendiri mean sebesar $77.63 \%$ meliputi: (a) motivasi (77.63\%), (b) citacita $(78.13 \%)$ dan (c) keinginan $(77.23 \%)$ ketiganya pada kategori "tinggi".

Faktor pengaruh dari lingkungan keluarga mean sebesar $70.51 \%$ pada kategori "tinggi", dengan indikator didalamnya meliputi: (a) pendidikan $(75.00 \%)$ dan (b) ekonomi (66.01\%) keduanya pada kategori "tinggi". Sejalan dengan penelitian Tarmono (2012) bahwa pengaruh yang nyata lingkungan keluarga terhadap minat siswa Siswa Kelas XII Program Keahlian Teknik Kendaran Ringan (TKR) pada SMK di Mranggen untuk melanjutkan pendidikan ke perguruan tinggi sebesar $40,5 \%$. Hal ini menunjukkan bahwa persentase faktor pengaruh minat pada SMK di Serang lebih besar.

Sedangkan untuk faktor pengaruh dari lingkungan sekolah diperoleh mean sebesar $65.32 \%$ pada kategori tinggi yang dipengaruhi beberapa indikator didalamnya yaitu: (a) alumni (64.09\%), (b) teman (58.54\%), dan (c) guru $(71.63 \%)$ untuk indikator teman pada kategori "rendah" sedangkan kedua diantaranya pada kategori "tinggi". Sejalan dengan 
hasil penelitian Proboyo, A. and Soedarsono, R. (2015) "For the attributes of the institution, the reputation and the values of the institution as well as the success of its alumni are the top three faktors that influence the decision in choosing the higher education institution".

Berdasarkan hasil regresi ganda maka faktor yang paling berpengaruh adalah 0.199 , hal ini menunjukkan peran diri sendiri sangat berpengaruh besar terhadap minat masuk perguruan tinggi yang dipengaruhi oleh cita-cita, keinginan dan motivasi. Faktor lingkungan keluarga memiliki koefisien korelasi sebesar 0.180 hal ini menunjukkan faktor keluarga sebagai faktor pertimbangan yang berpengaruh. Sedangkan faktor lingkungan sekolah memiliki koefisien korelasi sangat kecil yaitu 0.090, menunjukkan bahwa faktor lingkungan keluarga dan lingkungan sekolah sebagai faktor pertimbangan dalam melanjutkan ke perguruan tinggi. Hasil penelitian Supraptono (2007) menyebutkan besarnya korelasi faktor dari dalam anak, lingkungan keluarga, dan lingkungan sekolah terhadap minat masuk perguruan tinggi sebesar 0.376, 0.333 dan 0.290.

Apabila ingin meningkatkan masuk perguruan tinggi, maka yang perlu diamati adalah:

$Y=1.261+0.199 X 1+0.180 X 2+0.090$ $\mathrm{X} 3$ yaitu dengan meningkatkanfaktor diri sendiri, hal ini merupakan faktor yang sangat berpengaruh. Faktor yang lain sebagai faktor pertimbangan dalam melanjutkan perguruan tinggi.

\section{SIMPULAN DAN SARAN SIMPULAN}

Hasil analisis diketahui bahwa minat masuk perguruan tinggi siswa SMK kelas XII program keahlian Teknik Mesin dan Teknik Otomotif di Serang, termasuk kategori tinggi yaitu sebesar $71.76 \%$.

Besarnya sumbangan faktor-faktor pengaruh minat masuk perguruan tinggi yang terdiri dari dalam diri sendiri, lingkungan keluarga dan lingkungan sekolah masing-masing memiliki koefisien regresi sebesar 0.199; 0.180; dan 0.090. Faktor diri sendiri dan lingkungan keluarga secara bersama-sama mempengaruhi minat masuk perguruan tinggi sebesar $37,6 \%$. Dapat diasumsikan bahwa ada faktor pengaruh minat lainnya yang tidak termasuk dalam variabel penelitian.

\section{SARAN}

Melihat faktor dorongan dari dalam diri sendiri bahwa keinginan memperoleh hasil yang lebih baik, sebainya guru dan orang tua diharapkan lebih banyak memberikan arahan dan dorongan sesuai dengan keinginan siswa.

Melihat faktor lingkungan keluarga perolehan tinggi dari pendidikan, maka peran guru dan orang tua lebih leluasa mengarahkan pada keinginan dan program keluarga terkait pendidikan anak.

Melihat faktor lingkungan sekolah perolehan tertinggi adalah alumni, maka selain keingin dan dorongan, siswa harus banyak memperoleh informasi dari alumni terkait.

Diperlukannya penelitian lanjutan untuk melihat faktor pengaruh lainnya. Sehingga faktor keberhasilan dalam melanjutkan perguruan tinggi di Serang dapat meningkat.

\section{DAFTAR PUSTAKA}

Ali, M. (2009). Pendidikan untuk pembangunan nasional: menuju bangsa Indonesia yang mandiri dan berdaya saing tinggi. Grasindo.

Ali, M. (1985). Penelitian Kependidikan: Prosedur dan Strategi. Bandung: Angkasa.

Badan Pusat Statistik. (2016, Oktober). Retrieved 19 October 2016, from https://www.bps.go.id/linkTableDina $\mathrm{mis} / \mathrm{view} / \mathrm{id} / 1054$

Davis-Kean, P.E. (2005). The influence of perent education and family income in chils achievement: the indirect role of parental expectations and the home environment. Journal of family psychology. Vol. 19, No. 2. 294-304. 
Djaali, H., \& Djaali, H. (2011). Psikologi pendidikan. Jakarta: Bumi Aksara. https://doi.org/2011.

Djemari Mardapi. (2008). Teknik penyusunan instrumen tes dan nontes. Yogyakarta: Mitra Cendekia Press.

Hamalik, O. (2004). Proses belajar mengajar. Jakrata: Bumi Aksara.

Najafian, M. et. al. (2013). Factors affecting increase (decrease) in interest and guiding students towards higher education. Australian Journal of Basic and Applied Sciences. 7(7): 980-985.

Ninuk Indriyanti, Siswandari dan Elvia Ivada. (2013). Faktor-faktor yang mempengaruhi minat melanjutkan pendidikan ke Perguruan Tinggi pada siswa kelas XII Akuntasi SMK Negeri 6 Surakarta Tahun 2013. Jupe UNS. Vol. 1, N0.2, 1-10.

Okioga, C. K. (2013). The impact of students's socio-economic background on academic performance in Universities, a case of students in Kisli University Collage. American International Journal of Social Science. Vol. 2 No 2. 38-46.

Proboyo, A. and Soedarsono, R.. (2015) Influential Faktor in choosing higer education instituton: a case study of a private university in Surabaya. Jurnal Manajemen Pemasaran. Vol. 9., No 1. 1-7.
Slameto. (2003). Belajar dan faktor-faktor yang mempengaruhi. Jakarta: Rineka Cipta. https://doi.org/2003.

Suprapto. (2007). Minat Masuk Perguruan Tinggi Bagi Siswa Kelas III Program Keahlian Teknik Instalasi Listrik Pada SMK DI Purworejo. Laporan Penelitian UNNES.

Tarmono. (2012). Minat Masuk Perguruan Tinggi Bagi Siswa Kelas XII Program Keahlian Teknik Kendaran Ringan (TKR) Pada SMK Di Kecamatan Mranggen. GARDAN Jurnal IImiah Ikip Veteran Semarang. Vol. 2 No.1, 101-111.

Undang-Undang Republik Indonesia Tentang Sistem Pendidikan Nasional Nomor 20 Tahun 2003.

Williams, K.C. (2013). Five key ingredients for improving student motivation. Research in Heigher Educational Journal. 104-122. http://scholarworks.csustan.edu/han dle/011235813/645.

Winkel, S. \& S.j. (1984). Psikologi Pendidikan dan Evaluasi Belajar Jakarta: Gramedia. https://doi.org/1984 